\begin{tabular}{|c|c|c|}
\hline $\begin{array}{l}\text { Editor } \\
\text { Joe Bouch }\end{array}$ & & \\
\hline Editorial Board & Helen Killaspy & Trainee Editor \\
\hline Gwen Adshead & Femi Oyebode & Lisa Conlan \\
\hline J.S. Bamrah & Jan Scott & \\
\hline Dinesh Bhugra & Tom Sensky & Editorial Assistant \\
\hline Nick Brown & Steven Sharfstein & Jonica Thomas \\
\hline Patricia Casey & Michael Smith & \\
\hline David Castle & Peter Tyrer & Staff Editors \\
\hline John Cookson & Marc Woodbury- & Kasia Krawczyk \\
\hline Jonathan Green & Smith & Lynnette Maddock \\
\hline Julian Hughes & Daniel J. Smith & Zosia O'Connor \\
\hline $\begin{array}{l}\text { Sarah Huline- } \\
\text { Dickens }\end{array}$ & David Yeomans & \\
\hline
\end{tabular}

\title{
Subscriptions
}

Advances Volume 18, 2012 (six issues)

(full airmail £19/US\$34 extra)

Members of the
Royal College
of Psychiatrists Non-members Institutions

Print (+free online)

$\begin{array}{lccc}\text { Europe (\& UK) } & £ 50 & £ 140 & £ 151 \\ \text { USA } & \text { US } \$ 93 & \text { US } \$ 219 & \text { US\$260 } \\ \text { Elsewhere } & £ 58 & £ 150 & £ 163\end{array}$

Online (only)

Worldwide

Free $\quad £ 110 /$ US\$166 $£ 138 /$ US\$213

Payment may be made by cheque/money order, by Access/Master Card/ Visa/American Express, or by UNESCO coupons. EC subscribers: please supply your Member State Code and Value Added Tax (VAT) number.

Payment should be made to Maney Publishing, Suite 1C, Joseph's Well, Hanover Walk, Leeds LS3 1AB, UK (tel: +44 (0)113 243 2800; fax: +44 (0)113386 8178; email: subscriptions@maney.co.uk). For subscriptions in North America, please contact Maney Publishing North America, 875 Massachusetts Avenue, 7th Floor, Cambridge, MA 02139, USA (tel: 866 2975154 (toll-free); fax: 617354 6875; email: maney@maneyusa.com). Continuing professional development (CPD) Those wishing to register for CPD with the Royal College of Psychiatrists should contact the CPD unit (tel: $+44(0) 2072352351$, ext. 6108 or 6112$)$. There is no charge for participation in the CPD scheme for Members, Fellows and Affiliates of the College.

CPD Online The College also publishes an interactive online learning facility for CPD in psychiatry. Further details, sample modules and subscription information can be viewed at www.psychiatrycpd.co.uk. Discounts are available for Advances subscribers.

Correspondence Letters submitted for publication should be emailed to Dr Joe Bouch at apt@rcpsych.ac.uk or posted to Advances in Psychiatric Treatment, Royal College of Psychiatrists, 17 Belgrave Square, London SW1X 8PG.

Printed by Henry Ling Ltd, 23 High East Street, Dorchester, Dorset DT1 $1 \mathrm{HD}$.

(C) The Royal College of Psychiatrists 2012. Published by the Royal College of Psychiatrists, a charity registered in England and Wales (228636) and in Scotland (SC038369). Unless so stated, material in Advances in Psychiatric Treatment does not necessarily reflect the views of the Editor or the Royal College of Psychiatrists. The publishers are not responsible for any errors of omission or fact.

The College crest is a registered trade mark of the Royal College of Psychiatrists.

ISSN $1355-5146$

\section{Dependence or addiction?}

\author{
Joe Bouch
}

FROM THE EDITOR

Names matter. In the mid-1980s, the term 'dependence' was preferred to 'addiction' in DSM-III-R. Dependence was seen as a more neutral term; addiction as pejorative and leading to alienation of patients (O'Brien 2011). While there is a world of difference between 'non-addictive or therapeutic dependence' (Starcevic, pp. 250-258) and 'compulsive, uncontrolled, drugseeking behaviour' (O'Brien 2011) the same word, 'dependence', was used for both. Have patients and doctors alike conflated the two separate uses of the term? Tolerance, craving and misuse are infrequent in long-term benzodiazepine treatment rather than to be expected (Starcevic, pp. 250258). Withdrawal symptoms occur alike when selective serotonin reuptake inhibitors (SSRIs) or benzodiazepines are stopped, and suggesting that the 'discontinuation syndrome' of SSRIs represents something other is 'mere semantics' (Tyrer, pp. 259-262). Have benzodiazepines been underused as a consequence of such 'seldom-challenged myths' and is it time to reappraise their role (Starcevic, pp. 250-258)?

Gambling addiction, shopping addiction and internet sex addiction present new naming problems. Should the so-called behavioural addictions be regarded as mental disorders and, if so, are they addictions, compulsions or impulse control disorders? Both shopping addiction (Murali et al, pp. 263-269) and internet sex addiction (Dunn et al, pp. 270-277) are characterised by impulsive and compulsive behaviours. In other words, behaviours that are without foresight and persistently repeated despite adverse consequences (Robbins 2012). As in substance addictions, craving, diminished control, tolerance and withdrawal may all occur (Murali et al, pp. 263-269). Adverse consequences may be severe and there can be little doubt that sometimes treatment is justified (patient 2011). Gambling addiction as a focus for medical intervention is becoming better established (Bowden-Jones 2012) but there are concerns that currently 'the boundaries of the addiction concept [are expanding] beyond what is justified' (Smith, pp. 278-279).

\section{Internet sex addiction}

So then, do shopping addiction and internet sex addiction pass muster as mental disorders? Are they more akin to drug addictions or normal human behaviours? The article which is my Editor's pick explores whether internet sex addiction should be medicalised: 'before excessive interest in an activity or behaviour is declared an illness, effort must be taken to put it into a cultural and societal context' (Dunn et al, pp. 270-277). The authors highlight the advent of freely available pornography on the internet and consider media, scientific and feminist discourses. Taking a discursive approach, they conclude that internet sex addiction is a construct that lacks validity. They suggest that dispositional factors have been overstated at the expense of external influence and that internet sex addiction is 'a concept that obscures more than it illuminates'.

Bowden-Jones H, Smith N (2012) The medical management of problem gamblers. BMJ 344: e1559.

O'Brien C (2011) Addiction and dependence in DSM-V. Addiction 106: 866-7.

patient, Bowden-Jones H, George S (2011) A patient's journey: gambling addiction. BMJ 343: d7789.

Robbins TW, Gillan CM, Smith DG, et al (2012) Neurocognitive endophenotypes of impulsivity and compulsivity: towards dimensional psychiatry. Trends in Cognitive Sciences 16: 81-91. 